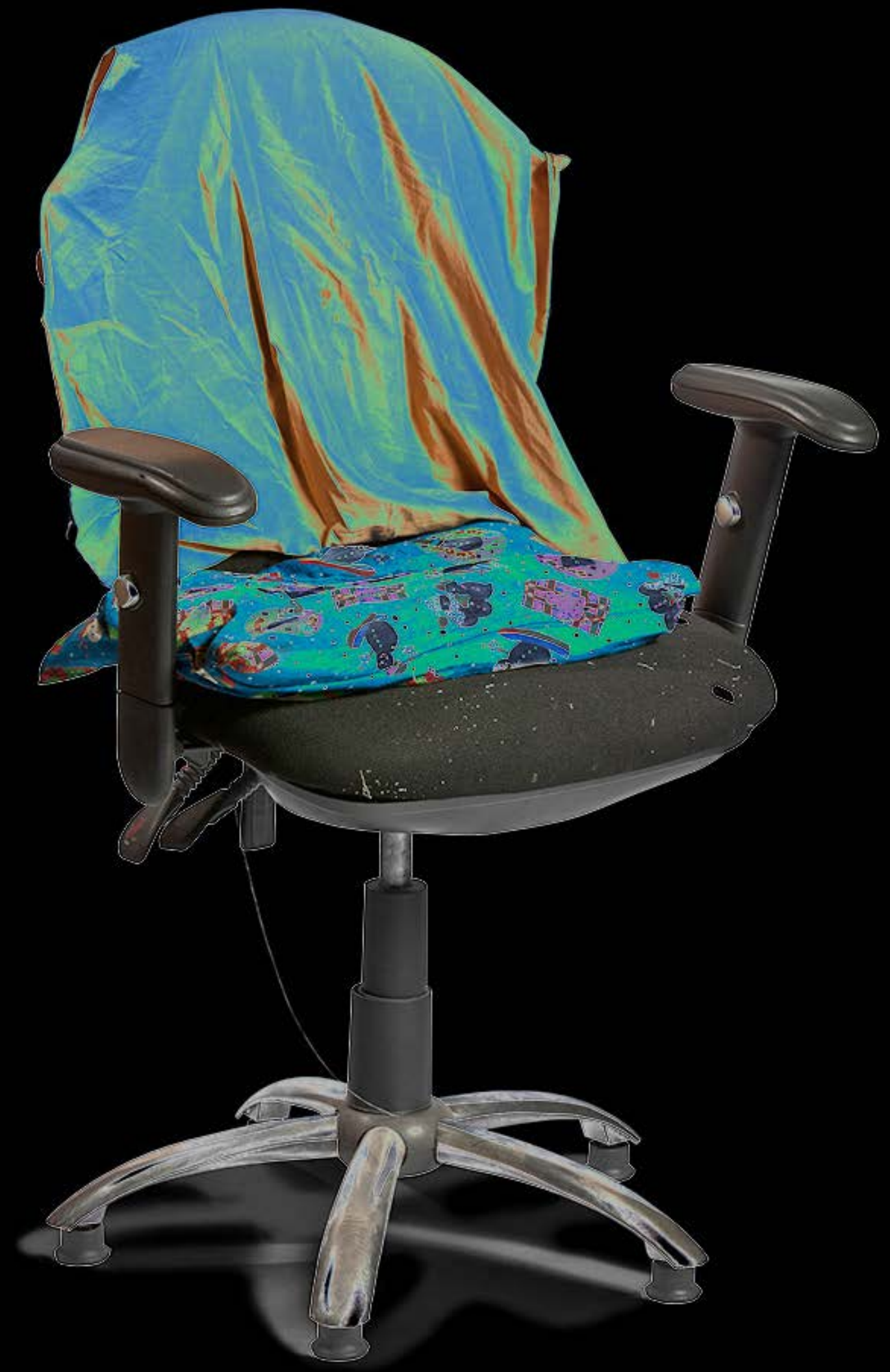




\title{
Agarrados de las manos. Datos para un somero panorama actual del arte plástico en Venezuela
}

\author{
Elizabeth Marín HeRnÁndeZ
}

Historiadora del arte de la Universidad de Los Andes, en Mérida, Elizabeth Marín Hernández deja en claro, en una charla que tuvimos para la revista Universidades, vía internet, México-

Venezuela, un poco de la situación que en estos días impera allá, en un país que, de a poco, se arma para sobrevivir una de las tradiciones más antiguas en el arte latinoamericano.

La reciente muerte del gran artista universal, Carlos Cruz-Diez, ¿cómo impactó en la tradición de la plástica venezolana?

Acá tenemos tres grandes artistas heroicos que equivalen a los muralistas mexicanos, los cinéticos, son la cara del país. Cruz-Diez era más diseñador que otra cosa, con casi todo lo que hizo como intervención urbana, sin embargo todo lo que dejó en el país está muy abandonado, y a su muerte el gobierno no hizo nada, ni un gesto. En el mundo del arte sí que lo sentimos mucho.

Todo el mundo de la cultura, por abajo del agua, está pensando cómo restaurar o rescatar la obra de Cruz-Diez en Venezuela, la herencia que artistas como él, Soto u Otero le legaron al país. Todos lo lamentamos muchísimo, pero no trascendió con ninguna muestra, revisión, ni nada, ningún tipo de honor por la parte de la institucionalidad.

\section{Llama la atención en el panorama actual venezolano la presencia de She- roanawe Hakihiiwee.}

Para nosotros es el Shero, a secas. Él es un artista que trabaja la abstracción indígena ritualista, y una de las cosas que pasó con él es que lo empezaron a mover en distintos ambientes, desde Abra Caracas manejada por Luis Romero, y su trabajo simbólico comenzó a destacar. El año pasado no sé cuántos premios le dieron a Shero, pero él al igual que lo que pasa con Cruz-Diez va por otro lado, lejos de la institucionalidad.

Él toma su tradición indígena y la trabaja desde los modos occidentales, en dos aguas, en dos caminos: por un lado está la materia que entiende una persona inmersa en esa simbolización y la otra, como nosotros, que sabe apreciarla.

\section{Habla un poco de la disyuntiva entre institucionalidad y la marginalidad que tanto mencionas.}

Cuando este régimen comienza, los campos del arte quedan relegados, se suspenden las ayudas, se posponen trabajos, los museos entran en preca- 
riedad, muchísimos artistas venezolanos emigran, y donde se esperaba que el arte se estudiara, se conservara, se promoviera, que son las instancias públicas con una potencia económica única, cada vez desaparecen más. Cada vez se desmantela más y se habla menos del arte venezolano hacia adentro.

Entonces en los últimos 20 años podemos decir que ha habido una deformación en la historia y todo lo que sería lo contemporáneo y lo histórico se ha ido mudando a lugares periféricos donde la expresión se sigue difundiendo sin castigo alguno.

Han surgido una gran cantidad de lugares sin la intervención del gobierno, como la ONG (Organización Nelson Garrido), el Avispero Art, o Espacio Proyecto Libertad. Pero aquí no ha habido una gran exposición que ande rodando el mundo, no ha habido la gran revisión de ninguno de nuestros artistas patrimoniales, nuestros artistas premios nacionales técnicamente están recluidos en sus casas con una pensión que de ser una promesa de mil dólares al mes ya no les queda nada.

El mundo se ha partido en dos tajos: está el lado donde el gobierno tergiversa la historia, llamando camarada a Picasso, hermanándolo con el régimen, inventándose un realismo social entre los decimonónicos, y del otro lado toda la parte académica, la investigación, los artistas que cuestionan el sistema político y del arte, todos los cuestionamientos están del lado contrario al régimen.

El mundo del arte son dos: el que ellos muestran, conveniente, a su altura, lo que ellos entienden como lo indígena, como lo propio, tratando de cambiar la memoria del país; y están los artistas que, independientes, continuaron la tradición tal como se concebía, por ejemplo Nelson Garrido, un artista premio nacional que ha cuestionado todo a su paso y ya no existe para la institucionalidad.

O el caso del Príncipe Negro, Rolando Peña, que cuestionó siempre el mundo del petróleo y para ellos igual no existe. Hay un teórico, Rolan Esteva Grillet, especialista en el siglo XIX que se dio a la tarea de escribir en un libro todas las erratas que está viendo en los museos, en las exposiciones de la institucionalidad desde hace años, para que cuando todo esto termine sacar a la luz todas las tergiversaciones que comete el gobierno.

\section{¿Qué nombres de artistas hay dentro de la institucionalidad?}

Es que no hay. No les interesa.

¿Entonces qué es lo que expone el gobierno en este capricho histórico del que hablas?

Reciclan lo que queda de las colecciones nacionales, mucho ya se ha perdido también, y nadie sabe, y con eso montan otra historia, una que les conviene. Inclusive no se ha mencionado nada del premio nacional del año pasado, y es porque no les interesa el trabajo de nadie. La gente que queda en los museos, a los que llamamos ángeles porque se encargan de cuidar lo poco que ya hay, están sin retrospectivas importantes, sosteniendo sin pies ni cabeza las colecciones, sin investigaciones, así han sido dos décadas. 
El único que ha mostrado artistas venezolanos fuera del país es Luis Pérez Oramas, quien fue curador del MoMa, y que ha llevado a Nueva York dos grandes exposiciones, una sobre Armando Reverón, uno de nuestros grandes pintores modernos, y la otra sobre Gego, y actualmente la de Jesús Soto en el Museo Guggenheim de Bilbao, curada por el español Manuel Cirauqui, pero de ahí, a fuera, nada. En los museos las piezas están mal ubicadas, lleno de ausencias, es una cosa angustiante. Yo tengo mucho tiempo que no piso los museo nacionales por la sensación de pérdida que me producen.

\section{Leí en estos días algo sobre el Salón de Jóvenes con FIA...}

La FIA es la Feria Internacional del arte de Caracas, ellos traían a muchas galerías de América Latina y del mundo a que expusieran. A medida que los controles se van cerrando sobre nosotros transportar obras de arte es complicado. La Fia prácticamente desapareció, pero ya tenía, antes de eso, la iniciativa de promover a Jóvenes con Fia, digamos el único salón de arte emergente en el país, y ellos han ido tomando mucha más fuerza porque no hay otro lado donde exponer. Lo complicado de este salón es que funciona por invitación. Se invita a un curador y este inicia su selección entre los artistas jóvenes, se monta la exposición y se premia de muchas formas y categorías lo que allí se expone.

Entonces, Jóvenes con FIA es un lugar en el que se estabiliza el arte joven para que no desaparezca, y el año pasado ganó el segundo lugar una alumna mía, Génesis Alayón, con la obra, Patrones de recorrido. Ella estudia en la Facultad de Arte en Mérida, y en el espacio alternativo que yo llevo tiene más de dos años trabajando. Era una chica que quería irse del país y la convencimos de que se quedara con un proyecto personal acá en Venezuela, y así comenzó su tesis sobre la crisis del transporte.

En el país, y más en mi región, el transporte público ha ido desapareciendo. La gente se monta en cualquier camión, fenómeno al que le llaman la perrera para cubrir sus trayectos. Ella comienza a hacer un registro de cómo la gente se va montando en estos precarios transportes, sin protección alguna, yendo para todos lados en una situación más que frágil. A partir de ese registro, Génesis crea un campo pictórico con una tensión enorme, porque ella coloca a la perrera como si se estuviera saliendo del espacio pictórico, en diagonal. Entonces pone a la gente en su cotidiano, con sus mochilas, con los portafolios, señoras mayores, que parecieran que se salen por completo de una normalidad. Todo es tensión en esos espacios.

Por otro lado, hay muchos jóvenes que están trabajando con fotografía, collages, performance e intervenciones, pero también hay una vuelta a lo pictórico, muy fuerte, un regreso a la pintura que ellos mismos consideraban pérdida, y entre esos pintores nuevos está Génesis.

\section{¿Cuál es la materia prima de la que echan mano esos jóvenes?}

Lo que encuentren. Reciclan telas, acrílicos, todo lo que puede funcionar. Esta crisis, en ese sentido, nos ha puesto más creativos, pues tenemos que solucionar y salir al paso con lo que tenemos. Los teléfonos han sido una herramienta fundamental para iniciar cualquier proyecto, pero al pasar del 
aparato hacia lo pictórico se conforman con lo que les funcione mejor, lo que les sirva: ropa sucia, cobijas, objetos en ruinas son la viva imagen de esta precariedad en la que nos encontramos dentro de la plástica.

\section{¿Cómo es el público de ese arte contemporáneo?}

Depende de donde estés. Donde yo vivo, ciudad universitaria, que tiene un público ideal: jóvenes que asisten a los espacios de arte, ávidos, discuten lo que ven en las salas. En Caracas, si bien va público joven, se diluye más el impacto porque hay mucha gente mayor, que quiere comprar. Todo se mueve en lugares periféricos, pues no se tiene el espacio ideal de esparcimiento del arte que anteriormente proveían los museos. Muchos artistas jóvenes quieren venir a Mérida, a la Universidad de Los Andes, por el perfil de la ciudad y de sus lugares de arte, donde aún se investiga y se escribe. A pesar de la división visible en el campo de exhibición existe un público bastante amplio para el arte contemporáneo en todo el país.

\section{¿Y cómo se vende?}

La pregunta. Yo no vendo. En Mérida es a lo que nos enfrentamos porque solamente hay profesores universitarios que no tienen ni para comer. En Caracas sí se vende, no igual que en otros tiempos, pero hay coleccionistas que ya están esperando la obra. Se vende de cara afuera del país, venden algunas galerías como por ejemplo: Abra Caracas, Carmen Araujo o D’Museo, todas ellas se mueven en todas las ferias posibles llevando obra a exhibir y vender afuera.

En Venezuela es un milagro que siga habiendo producción y que se siga moviendo el arte en esta situación.

\section{Y en esa situación, ¿̇el régimen se ha atrevido a censurar?}

A ellos no les interesa lo que pasa en el arte, pues se han de imaginar que somos tan pocos y nuestra esfera de acción es tan pequeñita, que aparentemente no les afectamos. Nelson Garrido hizo La balsa de los locos cuando inició la situación del país, y después hizo La balsa de la Medusa. En una exposición en la Universidad Central de Venezuela sobre su cuestionadora obra fotográfica, los colectivos de régimen la desmontaron de una manera violenta. No te avisan, mandan a un grupo de personas bastante violentas y la desmontan, incluso rompen las obras.

Con los lugares marginales, paralelos, fuera de la institucionalidad, no se meten porque somos pequeños, pero, por ejemplo, hace poco una asociación de defensa de derechos humanos, Provea (Programa Venezolano de Educación-Acción), volvió a editar discos de los años 80, con una canción que se llama ¿Qué hace usted, señor ministro?, y él les va diciendo que es un corrupto, que no trabaja, en fin. La fotografía de la portada del disco y el encarte es una obra de Nelson Garrido, un cuadro donde ves a la gente con la boina roja, la gente vestida de animal con máscaras de cerdo.

Un día antes de que saliera al diseñador del disco se lo llevan detenido e incautaron todo el material, y amenazaron peligrosamente a Nelson. 
Eso hizo mucho ruido en las redes sociales y la reacción del gobierno fue devolver al diseñador y el material, lo que logró que se vendieran muchos más discos, lo único es que, en vez de dar dinero por el disco, dabas una medicina porque esa era la campaña de Provea.

Juan Toro-Díez trabaja a través del medio fotográfico la violencia venezolana, y también hubo un encuentro, charlas y conferencias, donde él mostraba su interpretación de los escudos de las barricadas de las manifestaciones del 2017, la obra se llama Tropus, y en el momento en que él estaba hablando de la misma, junto con Johana Pérez Daza, los censuraron, los organizadores del evento les argumentaron que no podían usar las palabras "resistencia", "barricada", "guarimba", ni ninguna otra que se relacionara con el conflicto que vivimos, ni que lo expusiera, por evitar conflictos en las relaciones de la institución organizadora con el poder actual.

Entonces, hay un proceso de autocensura, no nos dejan hablar dependiendo de donde se esté. Les pasa también a los colombianos, que no usan las palabras "violencia", "asesinato", "necropolítica”, por ejemplo.

A mí no me han censurado en espacios privados, pero sí me han amenazado y hemos tenido que retirar una exposición en el 2017, cuando se vino el momento de las barricadas más fuertes. Yo monté una exposición con los muchachos que levantaban las imágenes todos los días de los hechos y nos pidieron que lo quitáramos, y obviamente tuvimos que alzar todo. Documentos de una protesta se llamó esa exposición en el Espacio Proyecto Libertad.

Tropus, por otro lado, eran unas pequeñitas cajas de luz donde Juan Toro montó una fotografía con una polaroid instantánea de los escudos de las barricadas. Desprendía de los formatos duros las imágenes y las colocó en los cajas, y fueron los organizadores de un evento en la sala Movistar de Caracas quienes le solicitaron el cambio de palabras como resistencia, es más los escudos que tenían la cara de Nicolás Maduro tuvieron que taparlos, fue algo vergonzoso y allí la autocensura.

\section{¿Y cómo, en ese contexto, se da la enseñanza del arte?}

En Mérida tenemos el Departamento de Historia del Arte más antiguo de toda América Latina, fue el primero que se fundó desde México hasta la Patagonia. De los quince profesores que éramos, quedamos la mitad en ese proceso de diáspora que ha afectado la vida de todos. Con sueldos miserables, precariamente, los que seguimos, seguimos manteniendo el Departamento en pie, con pocos alumnos se sigue, además con la responsabilidad de ya sentirnos encargados de historiografiar el arte en este momento. En Mérida se siguen enseñando de arte, en su Facultad de Arte, en nuestro Departamento, en Maracaibo en la Universidad del Zulia, en la Universidad Central de Venezuela en Caracas, y en otros centros como Bordes en San Cristóbal, somos pocos y al mismo tiempo muchos... No te voy a decir que estamos en perfecto estado de salud, pero estamos de pie, agarrados de las manos esperando a que nos derrumben. 